\title{
Chakra Genesis, A Correlation Between Evolution of Chakras \& Embryogenesis
}

\author{
Acharya Balkrishna ${ }^{1,2}$, Vinay Kumar Sharma ${ }^{1}$, Niti Sharma ${ }^{1 *}$ \\ ${ }^{1}$ Patanjali Research Institute, Haridwar, India \\ ${ }^{2}$ University of Patanjali, Haridwar, India
}

Submission: January 19, 2018; Published: November 06, 2018

*Corresponding author: Nitti Sharma, Patanjali Research Institute, Haridwar, Uttarakhand, India

\begin{abstract}
The Chakras are energy hubs in the body which are important for physical, mental, and spiritual comfort. They are located on the spinal cord where flow of energy is intensified due to congregation of energies from various neuronal centers. Every Chakra is also related to a specific endocrine organ which is helpful in healing of a blocked energy center. Abundant literature is available on presence of Chakras but there is a little understanding how the Chakras are developed during embryogenesis in the human body. The spine is one of the first things to develop in the fetus and it is well known that the Chakra system is present in the spine, it make sense to study the Chakra system of fetus and see how it evolves and effects the development of the child. Hence in the present article we aim to gather knowledge on how Chakras evolve within the mother's
\end{abstract} womb.

Keywords: Chakra; Embryogenesis; Endocrine system; Yoga

\section{Introduction}

The Chakra (Sanskrit: "wheel") - a swirling wheel of energy which provide vital force of life which are important for physical, mental, and spiritual comfort. They are not made of nerves but are powerful and subtle centers of energy. They are located on the spinal cord where flow of energy is intensified due to congregation of energies from various neuronal centers. Chakras are an integral part of Yoga [1] and get activated through Yoga practices particularly Pranayama (Controlled breathing) which help in directing spinal cord energy upwards by producing spark in motor and sensory nerves. The power of consciousness of the brain is also controlled by this flow of energy. Therefore, by achieving a command over the Chakra all glandular secretions and mental function can be controlled [2]. Several research articles supports the physiological effects of Yoga on central nervous system [3-7], cardiovascular system [8-16], autonomic nervous system [17-21] and respiratory system [22-25].

The earliest known mention of Chakras is found around 17001100 BCE in the Brahma Upanishad, Yogatattva Upanishad and Vedas [26]. These Vedic models were adapted in Tibetan Buddhism as Vajrayana theory, and in the Tantric Shakti theory of Chakras
[27]. The number of Chakras varies in different traditions of Yoga. Old Buddhist literature mentioned four Chakras which later got extended [28]. One hundred and twelve chakras were described [29] while others gave importance to seven Chakras [30-31]. The translation of two Indian texts, the Sat-Cakra-Nirupana, and the Padaka-Pancaka, by Arthur Avlon, in a book entitled The Serpent Power presented the idea of seven main Chakras in the West [32]. Vedas, the oldest scripture of world defined the eight chakras 'Astachakra navadvaradevanampurayodhya'. Out of the eight, five are situated on the spinal cord while the other three are related to brain [33]. Every Chakra is also related to a specific endocrine organ [34] which is helpful in healing of ablocked energy center. Abundant literature is available on presence of Chakras but there is a little understanding how the Chakras are developed during embryogenesis in the human body. The spine is one of the first things to develop in the fetus and it is well known that the Chakra system is present in the spine, it make sense to study the Chakra system of fetus and see how it evolves and effects the development of the child. Hence in the present review article we try to gather knowledge on how Chakras evolve within the womb (Figure 1) Table 1.

Table 1: Anatomical Location, Associated Gland and Diseases Related to Blocked Chakras.

\begin{tabular}{|c|c|c|c|c|c|c|}
\hline SN & Chakra & Location & $\begin{array}{c}\text { Derived } \\
\text { from }\end{array}$ & $\begin{array}{c}\text { Physiological system } \\
\text { concerned }\end{array}$ & Diseases due to blocked Chakras & $\begin{array}{c}\text { Associated Endocrine } \\
\text { gland }\end{array}$ \\
\hline 1 & Muladhara & Base of spine & Mesoderm & $\begin{array}{c}\text { Excretory system, Uri- } \\
\text { no-genital system }\end{array}$ & $\begin{array}{c}\text { Urinary diseases, kidney disorders, } \\
\text { genital disorders }\end{array}$ & Adrenal \\
\hline
\end{tabular}




\section{Journal of Yoga and Physiotherapy}

\begin{tabular}{|c|c|c|c|c|c|c|}
\hline 2 & Svadhisthana & $\begin{array}{l}\text { Below the } \\
\text { navel }\end{array}$ & Mesoderm & Reproductive system & $\begin{array}{l}\text { Infertility, tissue disease, genital } \\
\text { disorders }\end{array}$ & Adrenal \\
\hline 3 & Manipura & $\begin{array}{l}\text { Below the } \\
\text { chest }\end{array}$ & Endoderm & Digestive system & $\begin{array}{l}\text { Digestive system disorders, diabe- } \\
\text { tes, low immunity }\end{array}$ & Pancreatic \\
\hline 4 & Anahata & $\begin{array}{l}\text { Center of } \\
\text { the chest } \\
\text { (Thoracic } \\
\text { vertebra) }\end{array}$ & Mesoderm & $\begin{array}{l}\text { Circulatory system, } \\
\text { respiratory system, } \\
\text { Auto-immune system }\end{array}$ & Heart diseases, hypertension & Thymus \\
\hline 5 & Visuddha & $\begin{array}{l}\text { Thyroid and } \\
\text { para thyroid }\end{array}$ & Endoderm & Respiratory system & $\begin{array}{l}\text { Bronchial asthma, lung disorders, } \\
\text { thyroid, goiter }\end{array}$ & Thyroid \\
\hline 6 & Ajna & $\begin{array}{l}\text { Center of the } \\
\text { forehead }\end{array}$ & Ectoderm & Nervous system & Epilepsy, fainting, paralysis & Pineal \\
\hline 7 & Manas & $\begin{array}{l}\text { Below the } \\
\text { thalamus }\end{array}$ & Ectoderm & $\begin{array}{l}\text { Sensory and motor } \\
\text { system }\end{array}$ & $\begin{array}{l}\text { Psycho-somatic and neurological } \\
\text { disorders }\end{array}$ & Pituitary \\
\hline 8 & Sahasrara & $\begin{array}{l}\text { Top of the } \\
\text { skull }\end{array}$ & Ectoderm & Central nervous System & $\begin{array}{l}\text { Hormonal imbalances, metabolic } \\
\text { syndromes }\end{array}$ & Pituitary \\
\hline
\end{tabular}

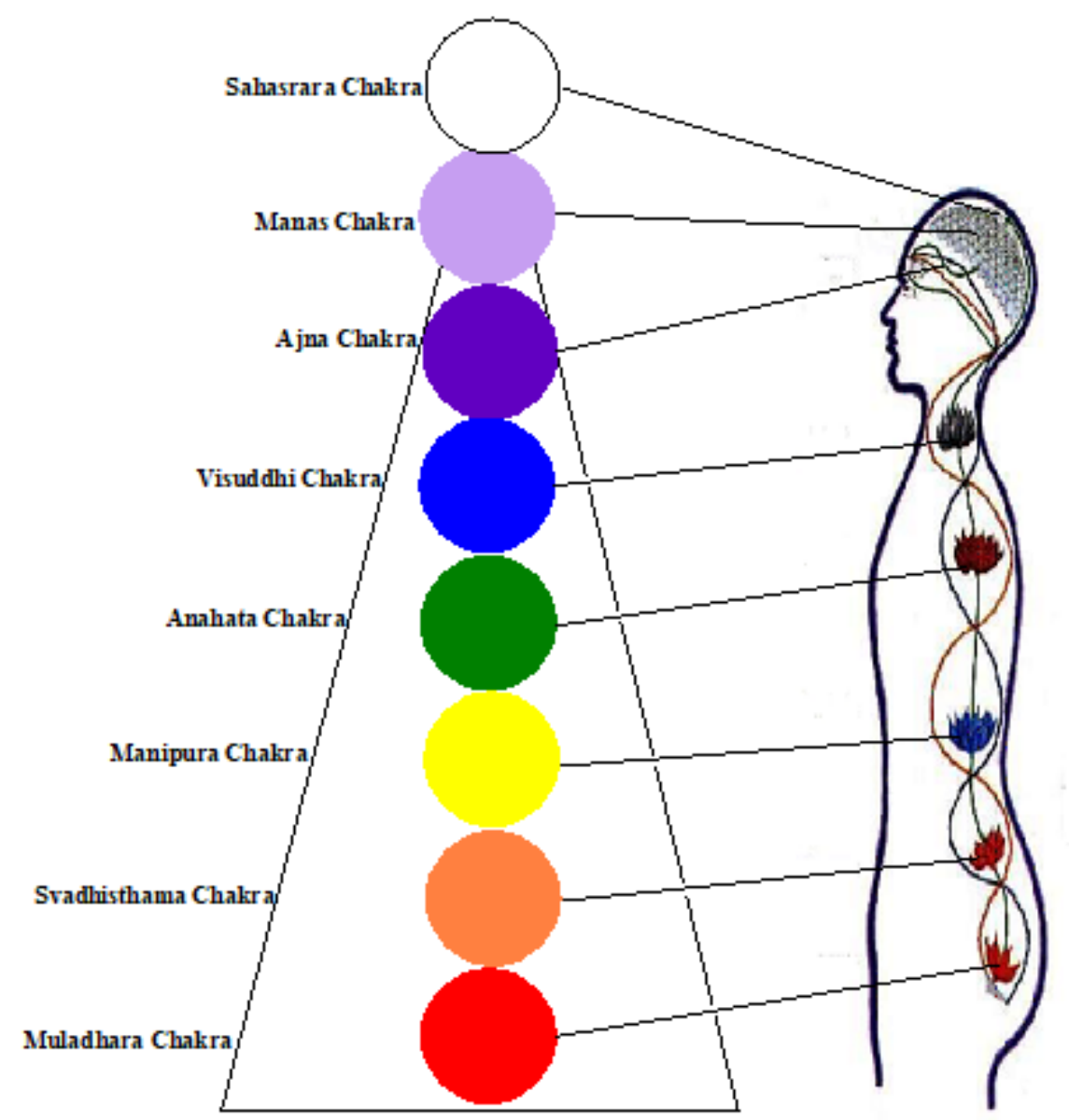

Figure 1: Position of Chakras in Human Body [54].

\section{Discussion}

During the initial stages of pregnancy, the embryo develops three germ layers. The innermost layer is called the endoderm which eventually forms digestive system, liver and lungs. The middle layer or mesoderm is the source of sex organs, bones, kidney and muscles. Ectoderm is the outer most layers, which forms the nervous system, skin and eyes [35].
Chakra system begins to develop during the first two months in the womb. The developing fetus at this stage is so attached with the life force energy that the Chakras are united together under one energy field i.e. at unanimity with the universe. As the embryo develops into afetus (after 8 weeks of fertilization), nervous tissue first develops as a flat sheet of cells called the neural plate. At an early point, the side edges of the neural plate begin to fold toward 
each other, ultimately forming a tube that mature into brain and spinal cord [36].

Thus the Sahasrara Chakra (Crown Chakra, the 8th Chakra) is the first to become active [37]. Meditation is the best way for the mother to support developing infant's Crown Chakra. During week 4 , the forebrain, middle brain, hind brain, and the optical stalk begin to develop [38]. The differentiation of midbrain from forebrain would make the physical base of the Sahasrára Chakra [1]. The brain hemispheres start to form at week 6 , and the brain waves begin. The hind brain develops during week 8 , and controls the heart rate, breathing, and muscle movement. The nervous system is ready for functioning at $9^{\text {th }}$ week and the brain develops approximately 25 million neurons per minute. During $15^{\text {th }}$ week the spinal nerves emerge from the spinal cord and by week 19, the brain is able to form motor neurons, which allow the body to produce movement voluntarily. By the end of week 26 , the brain's surface area increases due to folding.

After the formation of brain, motor and sensory neurons start functioning. The development of the fetus brings it closer to the material world even though they are engrossed in the spiritual world of the womb. The body organs began to differentiate, blood cells and hormones start forming and the fetus continues to grow. Along with that the Chakras also began to segregate. The heart is the first organ to be formed by day 22 or 23 after conception (week five of pregnancy), the heart begins to beat and can be noticed in vaginal ultrasound as a weak flicker. Initially heart is formed as a tube which later becomes fully functional by the end of week eight of embryonic development [39]. In four weeks after conception, the neural tube along fetus back is closing and heart is pumping blood. Embryo does not experience any kind of pain during first three months of pregnancy. It starts experiences consciousness after three weeks. It suggests that the soul (Atma) enters the body at this time [33] during the formation of Anahata Chakra (Heart Chakra, 4th Chakra). It lies at the center of the chest and includes the heart, cardiac plexus, thymus gland, lungs, and breasts besides ruling the lymphatic system.

Manas Chakra ( $7^{\text {th }}$ Chakra) lies directly above Ajna Chakra and mostly considered as a minor Chakra. It consists of six petals, one for each of the five senses and one for sleep. These petals are normally white but adopt the color of the senses when stimulated by them, and turn black at the time of sleep. This Chakra is responsible for sending sense perceptions to the higher Chakras.

The Third Eye Chakra (Ajna Chakra, $6^{\text {th }}$ Chakra) becomes active around 7 weeks after conception. It is a bridge that permits mind communication between two people. According to the Hindu belief the spiritual energy enters the body through this gateway and sometimes called 'seat of soul' [40]. Ajna has two petals, represent the pineal and pituitary glands, said to represent the psychic channels (nadis) Ida and Pingala, which meet the central Sushumna nadi before rising to the Crown Chakra. Pineal gland, which regulates the circadian rhythm, is light-sensitive gland that is why it is called the 'third eye'. It is also sometimes linked with the pituitary gland, the chief endocrine gland. This gland produces a melatonin and a powerful psychedelic chemical called DMT (N,N dimethyltryptamine). In normal human DMT is released in large amounts during two times in life: once at birth and at time of death [41]. From an embryological point of view, the most likely site of Ajna Chakra is the highly studied isthmus organizer that controls the differentiation of midbrain from hind brain structures [42]. Mother can develop this Chakra of her unborn baby by reading and speaking with her child on a mental level.

The Vishuddhi Chakra ( $5^{\text {th }}$ Chakra) is located in the vicinity of the Larynx- and is therefore also known as the Throat Chakra. It regulates the functional regions of the thyroid, parathyroid, jaw, neck, mouth, tongue, and larynx. The thyroid is one of the initial endocrine organs to differentiate and has an important hormonal role in embryonic development. The thyroid gland is formed from two groups of embryonic cells by first dividing to form two lobes parted by a narrow connecting isthmus [43]. These two structures became obvious by 16 to 17 days of gestation. However, by 20 weeks only the fetus is able work through feedback mechanisms for thyroid hormones production [44]. Development of larynx starts during the $4^{\text {th }}$ week and is closely connected with the development of trachea. The development starts in the form of laryngotracheal groove in the ventral wall of the pharynx. The groove steadily deepens and its edges fuse to form a septum which splits the laryngotracheal tube from the pharynx and oesophagus. This tube is lined with endoderm from which the epithelium of the airway develops. The cranial end of this laryngotracheal tube forms the larynx and the trachea while the other end of tube produces two branches from which the two main bronchi develop. This is also the place from which the two lung buds starts to develop.

The Pranayama has tremendous effect on the Vishuddhi Chakra, at both the physical and spiritual levels. The harmful materials are release from the body on a physical level, and spiritually the beliefs, sentiments, conscious and subconscious are cleansed and synchronized. To boost cognizance in the developing baby the mother can communicate with the baby by speaking or by playing music etc.

The third Chakra is called Manipura (Solar Plexus Chakra), which is located around the navel and extends up to the breastbone [45]. It is a source of personal power that governs self-esteem and also has the power of transformation. This Chakra has role in controlling metabolism and digestion too. Through this Chakra we absorbs solar energy with revitalize our etheric and physical body [46]. Manipura is "the center of etheric-psychic intuition" that is why listening to 'gut feeling' may help in making better decisions in life [47].

Initially, the digestive system is a series of tubes starting from mouth and terminating at anus. By about 8 weeks of gestation stomach starts forming and by 10th week start to produce gastric juices. The complete development of digestive system takes 32 weeks. The rudimentary structure of the eyes, ears, and smell develops early in gestation along with sensation for touch, position, and motion detection. Brain development includes sensory systems, motor systems, social/emotional systems, and 
cognitive systems. The motor development occurs during six to ten weeks, in which the fetus starts to move its limbs and mouth. Sensory development begins at 8 weeks and progresses rapidly. The first sense to develop is touch followed by taste at 14 weeks. The ear is fully developed at 24 weeks, even though the fetus can react to sound by 16 weeks. The eyes open at 26 weeks but the ability to focus is developed toward the end of the pregnancy [48]. All of these systems are related and work together throughout late fetal and early neonatal life. All exogenous or outside sensory stimulation has an emotional component as well as the sensory component [49].

The pineal gland becomes visible at 49 th day or 7 th week after conception. During this time only sex differentiation takes place and gender is determined. The pineal gland influences the pituitary glands secretion of Follicle Stimulating Hormone and Luteinizing Hormone through some other transmitting molecule [50]. During this period the Sacral Chakra (Svadhisthana Chakra, 2nd Chakra) begins to develop and determine the sexuality during physical development. It is located above the pubic bone - below the navel, incorporating the genitals and the hypogastric plexus. The mother should engage in creative activities (writing, painting and paying music) to convey that verve to the baby.

The Muladhara Chakra (Root Chakra, 1st Chakra) is the foundation of the energy body. The root chakra is also associated with what is referred to as a psychic knot. Specifically, Muladhara Chakra is known as the Brahma granthi. This is like a knot of energy in the body. When this knot of energy is released, it allows us to enter Brahma Loka. It also purifies and balances energy in the urogenital region. The root Chakra becomes active when the baby changes its position and places the head in the birth canal. The child is ready to emerge from mother's womb and greet the material world. Thus in other words the Root Chakra relates to the survival needs, will to live, and sense of trust. Children with enough Root Chakra energy will be less prone to illness and have a stronger chance for survival. Mother's contentment and sense of security during this time will have a deep influence on the child's root Chakra.

The urogenital system starts developing during the fourth week from urogenital ridges in the intermediate mesoderm on each side of the primitive aorta. Both urinary and genital systems are interwoven and develop together. The nephrogenic ridge is the part of the urogenital ridge which forms the urinary system. Urine formation begins towards the end of the first trimester (weeks 11 to 12). Three sets of kidneys also develop consecutively in the embryo. The pronephros is nonfunctional and disappears very early; the structural elements of the mesonephros mostly degenerate, but the gonad is developed in their place, with which the Wolffian duct remains as the duct in males, and the Müllerian as that of the female.

Maxwell proposed a gap junction theory according to which physical systems related to a Chakra have three key features: (i) a physical base present in the dorsal CNS, (ii) a concentration point activating the physical base, (iii) and impact of that physical base on secretions from a particular gland which in turn affect the brain function. The gap junctions in the autonomic plexuses may become activate in the dorsal CNS, once energized. Moreover, gap junctions also modulate glandular functions, apparently by autonomic nerves linked with these dorsal CNS positions.

\section{Conclusion}

Previous efforts to correlate physical body and Chakra were inadequate. Additional information about stages of embryogenesis along with the formation of Chakras may be helpful in proposing a different aspect of Chakra theory. This is backed by the gap junction concept proposed by Maxwell according to which Chakras must have physical connection in addition to the apparent metaphysical features.Chakras have more than one dimension to them. One dimension is their spiritual while other is physical existence. The literaturehas described the Chakras as metaphysical equivalent of the endocrine glands, as noticeable similarity between the positions of the two has been observed [51]. Sturgess also linked the lower six chakras to specific nerve plexuses along the spinal cord as well as with the glands [52]. Likewise, the Ajna Chakra is linked with the pineal gland which is a part of the endocrine system [53]. These associations remain speculative, however, and have yet to be empirically validated. Initially, all Chakras are fused under one powerful energy source which gradually separates and develops along with the fetal development. The mother need to focus on meditation, creative activities, and positive thinking etc. all have tremendous role in strengthening the Chakras of growing fetus in the womb.

\section{References}

1. Maxwell R (2009) The physiological foundation of yoga chakra expression. Zygon 44(4): 807-824.

2. Sarkar SPR (1994) Yoga Psychology. (2 $2^{\text {nd }}$ edn), In: Ánanda M (Ed.), Glands Subglands, Calcutta, India, pp: 121.

3. Elson BE, Reter H, Cunis D (1977) Physiological changes in yoga meditation. Psychophysiol 14(1): 52-57.

4. Corby JC, Walton TR, Vincent PZ Jr, Bert SK (1978) Psychophysiological correlates of the practice of tantric yoga meditation. Arch Gen Psych 35(5): 571-577.

5. Lazar S, Bush G, Gollub RL, Fricchione GL, Khalsa G, et al. (2000) Functional brain mapping of the relaxation response and meditation. Neuro Report 11(7): 158-185.

6. Pete A, Peper E, Kawakami M, Gibney KH (2001) The physiological correlates of kundalini yoga meditation: A study of a yoga master. Appl Psychophysiol Biofeedback 26(2): 147-153.

7. Aftanas L, Semen G (2005) Impact of regular meditation practice on EEG activity at rest and during evoked negative emotions. Int J Neurosci 115: 893-909.

8. Patel C, Marmot MG, Terry DJ, Carruthers M, Hunt B, et al. (1985) Trial of relaxation in reducing the coronary risk: Four year follow up. Br Med J (Clin Res Ed) 290(6475): 1103-1106.

9. Bernardi L, Sleight P, Gabriele B, Simone C, Lamberto F, et al. (2001) Effect of rosary prayer and yoga mantras on autonomic cardiovascular rhythms: Comparative study. Br Med J 323(7327): 1446-1449.

10. Raub J (2002) Psychophysiologic effects of hatha yoga on musculoskeletal and cardiopulmonary function: A literature review. J Alt Compl Med 8(6): 797-812. 
11. Bharshankar G, Geeta B (2003) Effect of yoga on cardiovascular system in subjects above 40 years. In J Physiol Pharmacol 47 (2): 202-206.

12. Kasiganesan H, Malhotra AS, Pal K, Prasad R, Kumar R, et al. (2004) Effects of hatha yoga and Omkar meditation on cardiorespiratory performance, psychologic profile and melatonin secretion. J Alt Compl Med 10(2): 261-268.

13. Patil S, Telles S (2006) Effects of two yoga based relaxation techniques on heart rate variability (HRV). Int J Stress Manage 13 (4): 460-475.

14. Choudhary S, Choudhary R, Chawala VK, Soni ND, Kumar J, et al. (2013) Effects of Yoga and physical exercise on cardio-respiratory parameters. Natl J Integr Res Med 4(3): 50-55.

15. Maini S, Kaur H, Maini N (2011) Effect of Rajyoga meditation on the heart rate blood pressure and ECG. J Clin Diag Res 5(8): 1519-1522.

16. Chaturvedi DK, Arora, JK, Bhardwaj R (2015) Effect of meditation on Chakra energy and hemodynamic parameters. Int J Com Appl 126(12) 52-59.

17. Wenger MA, Bagchi BK (1961) Studies of autonomic functions in practitioners of Yoga in India. Behav Sci 6: 312-323.

18. Bujatti M, Riederer P (1976) Serotonin, noradrenaline dopamine metabolites in transcendental meditation-technique. J Neu Trans 39(3): 257-267.

19. Vempati RP, Telles S (2002) Yoga-based guided relaxation reduces sympathetic activity judged from baseline levels. Psychol Rep 90 (2): 487-494.

20. Streeter CC, Gerbarg PL, Saper RB, Ciraulo DA, Brown RP (2012) Effects of yoga on the autonomic nervous system, gamma-aminobutyricacid, and allostasis in epilepsy, depression, and post-traumatic stress disorder. Med Hypotheses 78(5): 571-579.

21. Amihai I, Kozhevnikov M (2015) The influence of Buddhist meditation traditions on the autonomic system and attention. Biomed Res Int 731579.

22. Bhargava RM, Gogate G, Mascarenhas JF (1988) Autonomic responses to breath holding and its variations following Pranayama. In J Physiol Pharmacol 32(4): 257-264.

23. Telles S, Nagarathna R, Nagendra HR (1994) Breathing through a particular nostril can alter metabolism and autonomic activities. In J Physiol Pharmacol 38(2): 133-137.

24. Spicuzza L, Gabutti A, Porta C, Montano N, Bernardi L (2000) Yoga and chemoreflex response to hypoxia and hypercapnia. Lancet 356: 14951496.

25. Brown RP, Gerbarg PL (2005) Sudarshan Kriya yogic breathing in the treatment of stress, anxiety and depression: Part I-neurophysiological model. J Alt Compl Med 11(1): 189-201.

26. Fenton S (2009) Simply Chakras. Sterling Publishing Company Inc, New York, USA

27. Gordon WD (2003) Kiss of the Yogini. University of Chicago Press, Chicago, USA.

28. Gordon WD (2011) Yoga in Practice. Princeton University Press, New Jersey, USA.

29. Sadhguru (2017) Adiyogi: The Source of Yoga. Harper Collins Publishers, India.

30. Grimes J (1996) A Concise Dictionary of Indian Philosophy: Sanskrit Terms Defined in English. State University of New York Press, USA, pp: 100-101.
31. Feuerstein G (1997) The Shambhala Encyclopedia of Yoga. Shambhala, Boston, USA.

32. Avalon A (1974) The Serpent Power: The Secrets of Tantric and Shaktic Yoga. Dover, New York, USA.

33. Balkrishna A (2017) Yog Vijnanam. Divya Publications, India

34. Khalsa DS, Cameron S (2002) Meditation as Medicine: Activate the Power of Your Natural Healing Force. Fireside, New York, USA.

35. Kate MC (2013) The Embryo Project Encyclopedia. Arizona State University, Arizona, USA.

36. Gammill LS, Marianne BF (2003) Neural crest specification: Migrating into genomics. Nature Rev Neurosci 4(10): 795-805.

37. Kalashatra G (2004) A Handbook of Chakra Healing: Spiritual Practice for Health, Harmony and Inner Peace. ( $1^{\text {st }}$ edn), CT: Konecky \& Konecky Publishers, USA.

38. Rubenstein J, Shimamura K, Salvador M, Luis P (1998) Regionalization of the prosencephalic neural plate. Ann Rev Neurosci 21(1): 445-477.

39. Perkins S (2015) A description of the fetal heart development stages.

40. Lokhorst GJ (2016) Descartes and the Pineal Gland, (Summer edn), In: The Stanford Encyclopedia of Philosophy. Edward NZ (ed.), Stanford University, USA.

41. Strassman R (2001) DMT: The Spirit Molecule. A Doctor's Revolutionary Research into the Biology of Near-Death and Mystical Experiences, Rochester, USA.

42. Paula A, Wassef M (2003) The isthmic organizer links anteroposterior and dorsoventral patterning in the mid/hind brain by generating roof plate structures. Development 130(22): 5331-38.

43. Gardner D, Shoback D (2011) Greenspan's Basic \& Clinical Endocrinology. ( $9^{\text {th }}$ edn), McGraw Hill, New York, USA.

44. Balasubramanian T (2015) Anatomy of larynx. Otolaryngology Online Journal 5(1.5): 1-13.

45. Leadbeater CW (1994). The Chakras. The Theosophical Publishing House, Wheaton, USA.

46. Katzman M (2015) The Solar Plexus Chakra: The Third Chakra Manipura Guide. Kindle Edition.

47. Graven S, Browne J (2008) Sensory Development in the Fetus, Neonate, and Infant: Introduction and Overview. Newborn Infant Nur Rev 8(4): 169-172.

48. Purvis B (2005) Prenatal Sensory Development. The NICU Experience: Its Impact and Implications, Virginia Early Intervention Conference, Roanoke, USA.

49. Braverman L, Cooper D (2004) The Thyroid: A Fundamental and Clinical Text. (10 $\left.{ }^{\text {th }} \mathrm{edn}\right)$, Lippincott Williams and Wilkins, USA.

50. Motta M, Fraschini F, Martini L (1967) Endocrine effects of pineal gland and of melatonin. Exp Biol Med 126(2): 431-435.

51. Gardiner P, Osborn G (2006) The Shining Ones: The World's Most Powerful Secret Society Revealed. Watkins Publishing, London, UK.

52. Gyurme T (2013) 8-Alchemy: The Alchemy of the Soul. Lulu Press Inc, USA.

53. Sturgess S (2015) The Yoga Book: A Practical Guide to Self-Realization. Watkins Publishing, London, UK.

54. Balkrishna A (2013) A Practical Approach to the Science of Ayurveda. Divya Prakashan, India. 
This work is licensed under Creative Commons Attribution 4.0 License

DOI: 10.19080/JYP.2018.06.555694

\section{Your next submission with Juniper Publishers} will reach you the below assets

- Quality Editorial service

- Swift Peer Review

- Reprints availability

- E-prints Service

- Manuscript Podcast for convenient understanding

- Global attainment for your research

- Manuscript accessibility in different formats

( Pdf, E-pub, Full Text, Audio)

- Unceasing customer service

Track the below URL for one-step submission

https://juniperpublishers.com/online-submission.php 